\title{
Reserve Holdings and Macroeconomic Variables: An Empirical Dynamic Analysis in Egyptian Economy
}

\author{
Osama M. Badr and Ahmed F. El-khadrawi
}

\begin{abstract}
This study aims to investigate the long run relationship of international reserves holding in Egypt using the buffer stock model presented by Frenkel and Jovanovic (1981). The study employed quarterly data from 1990Q1 to 2012Q4. A robust time series technique autoregressive distributed lag (ARDL) was used which is applicable irrespective of whether the regressors are purely I (0) or purely I (1). The evidence derived from the ARDL approach support the fact that the scale variables and the volatility variable have significant effects on the reserve demand. The evidence also demonstratesthat both exchange rate flexibility and opportunity cost does not have any significant impact on the reserve demandin Egypt.
\end{abstract}

Index Terms-International reserve holdings, Egyptian economy, autoregressive distributed lag (ARDL).

\section{INTRODUCTION}

The recent economic crises have raised a debate regarding the level of reserves as indicators of the strength of a country's economy. There have been beliefs that reserves can reflect economy's ability to deal with cash inflows sudden stops shocks. Low income countries are more vulnerable to shocks of sudden stops inflows such as terms-of-trade shocks, a natural disaster or political instability, which result high macroeconomic volatility imposes large welfare costs, thus high reserves has been considered as insurance against the risk of cash inflow sudden stop crises [1]. This mean that the most important problems face low income countries is how to meet emergency financing needs, especially if the country reliance on international trade to import substantial amounts of its necessity needs, in the same time, rely on noncompetitive export sectors to generate most of its foreignexchange inflows. So, if there is an unexpected imbalance in foreign exchange inflows, an appropriate amount of international reserves can play a critical role in the face of such imbalances. Therefore, a country can avoid large imports fluctuations due to such problems and provide the national economy stability to face speculative attacks against the national currency and minimize the negative impact of such shocks. In this context, international reserves are not only working to avoid shocks, but also can play a role in mitigate crisis consequences. However, the main problem faced policymakers, that they often compare

Manuscript received January 4, 2015; revised March 18, 2015.

Osama M. Badr was with the Faculty of Commerce, Tanta University, Egypt, and is with the College of Business, Umm Al-Qura University, KSA (e-mail: ombadr@uqu.edu.sa).

Ahmed F. El-khadrawi was with the Faculty of Commerce, Damietta University, Egypt, and is with the Faculty of Islamic Economic and Finance, Umm Al-Qura University, KSA (e-mail: afkhadrawi@uqu.edu.sa). between the rate of return of reserves holding and interest rate government must bay on its long-term external liabilities.

However, the authority in low income countries feel that the opportunity cost of holding reserves is small compared to the economic costs resulting from the crisis which will lead to currency depreciation raising the cost of imports [2]. From this aspect, countries always hold a huge stockpile of reserves as a precautionary measure due to their restricted access to international capital markets [3]. In this paper, we investigate the determinants of the demand for international reserves focusing on the Egyptian case over the period 1990-2012.The importance of this study can be attributed to two main reasons. First, Egypt has historically faced by many external shocks during the period started with gulf war through the financial crisis in the nineties expiration plus the revolutions that occurred in the years 2011 and 2013, which certainly influenced the stockpile of international reserves in Egyptian economy. Furthermore, important question have been raised about the level of reserves that Egypt should keep to face such external shocks and what is the determinants affecting the stockpile of this reserves. Second, lack of studies aimed at addressing this issue in Egyptian economy context.

The rest of our study is organized as follows; Section II literature reviews that discuss the determinants of the demand for reserves. Section III focuses on the Egyptian case and provides a brief description of the pattern of evolution of reserves during the period of the study. Section IV presents the empirical model and its extension to be used in the estimation, discusses the estimation technique. The empirical results and discussion was taken care of in Section V. Last section contains a brief summary and the important conclusion derived from the study.

\section{LITERATURE REVIEW}

Holding international reserves is not new concept, it goes back to the 1960s where Hiller (1966) argue that there is a negative relation between demand for international reserves and the marginal propensity to import. Where "The amount of dampening necessary to attain external balance is inversely proportional to the propensity to import", thus, a lower demand for international reserves. He quantifies the reserve level that a country must be held by weighting the costs of adjustment resulting from external imbalances against the opportunity cost of holding reserve ${ }^{1}$ [4].

${ }^{1}$ The total cost of adjustment is given by $\mathrm{TC}=\Delta \mathrm{B} / \mathrm{m}$, where $\Delta \mathrm{Bis}$ the amount of external imbalance, $m$ is the propensity to import. While the opportunity cost of holding reserves is the difference between the rate of return on social capital and the rate of return on international reserves 
Frenkel and Jovanovic define reserves as a buffer stock to accommodate stochastic fluctuations in external payments imbalances. Where authorities endure adjustment cost when their reserves reach undesirable lower bound. which means, that authority will be willing to retain higher level of reserves to deal with the volatility of international transaction, thus tolerate greater opportunity cost in order to incur less adjustment cost [5].

Flood and Marion re-estimates the equation presented by Frenkel and Jovanovic (1981) with different scaling variables. They found that the only significant variables was the reserves volatility, with an elasticity of 0.5 or more in almost all of the regressions [6]

Lan and Burke study the determinants of the demand on international reserves for a group of countries during the period 1981-1995. They found that among all variables used in the study, the openness is the most important contributing factor for demand on international reserves [7].

Aizenman and Marion studied the determinants of some variables which influencing the decision to hold international reserves in developing countries such as the volatility of international transactions, the exchange rate arrangement, and political instability. They found that countries often increases their demands on the international reserves for precautionary purposes, because two reasons, first is sovereign risk, the second is the inability to impose more taxes to cover its financial obligations. They also argued that there is a negative relation between political instability and the stockpile of international reserves held by the authorities for precautionary reasons [3].

Some studies adopt a different view such as Dooley et al. They follow a modern mercantilist approach by Looking to reserves as an integral part of a country's export promotion strategy. They argue that the normal evolution of the international monetary system involves the emergence of a periphery for which the development strategy is export-led growth supported by undervalued exchange rates, capital controls and official capital outflows in the form of accumulation of reserve asset claims on the center country [8]. However, Aizenman and Lee, recognized that variables associated with mercantilist motives are statistically significant, but economically not important in explaining the patterns of holding reserves. In contrast, variables associated with precautionary motives (openness and exposure to financial crises) are statistically and economically important in explaining the holding of international reserves [9].

Dooly et al. offers a link between capital flows and international reserves holdings. They argue that emerging economies accumulate reserves to secure FDI inflows from center countries like U.S. According to this view, there is appositive correlation between capital inflows and reserves holdings [10].

Ramachandran applied the buffer stock model on the Indian case. He finds that in contrast with most empirical studies, the common measure of volatility "as rolling standard deviation of reserve increment" provides upwardly bias. As a result he used an alternative measure of volatility derived from GARCH models and fined that new measure removed the bias and improved the result which became closer to the theoretical prediction [11].
Ball and Reyes re-estimate the model presented by Flood and Marion (2002) to investigate about the significant of interest rate as a determinant of the optimal reserves under different monetary systems [12]. They argue that interest rates did not have a significant effect under the fixed exchange rate system because of the endogeneity problem between interest rates and international reserve holdings. For control this endogeneity they introduce (2SLS) estimation and find that interest rate is significant determinant.

\section{AN OVER VIEW OF EGYPTIAN RESERVE HOLDINGS: A BRIEF TRENDS EXAMINATION}

In this context we will discuss two points, first the historical evolution of the stockpile of the Egyptian international reserves. Second the shocks Egypt has been faced during the period 1990-2012 and its impact on macroeconomics variables volatility.

Firstly we should define the concept of international reserve. According to Heller qualities, we can identify four types of assets that fall under the term "international reserves, official holdings of gold, special drawing right (SDR), foreign currency assets of the monetary authority, and the reserves position in the IMF [4].

Despite the fact that gold is one of basic components of foreign reserves held by the country, but the relative importance of this component decreased [6]. This vision about excluding gold because whether central bank consider gold as liquid as foreign currency holding to be used it as an intervention asset.

In our examination we use reserves including gold as a measure of international reserves. The figure in Appendix 1 shows Cash inflow sudden stop Shocks occurs when the expected revenue decline suddenly leading to reduce the international reserves stockpile as a result of Government's attempt to cover domestic demand plus debt service payment.

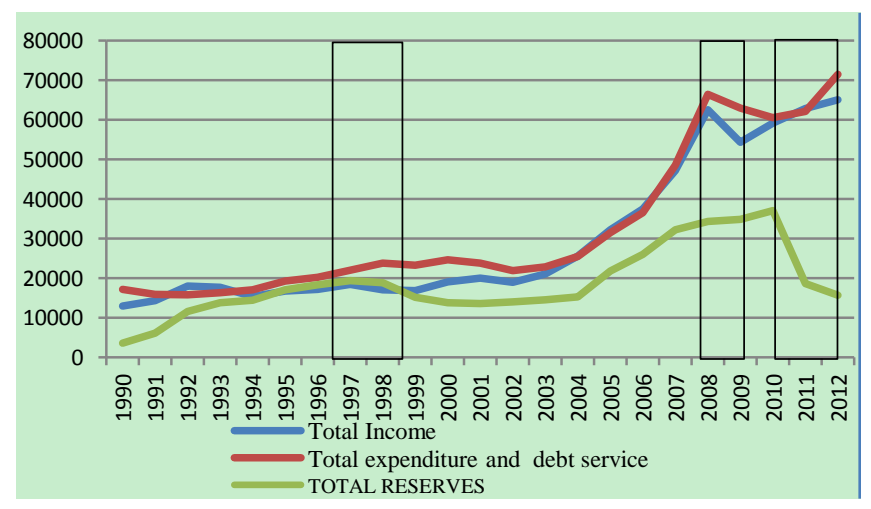

Fig. 1. Economic shocks and Egyptian reserves behaviors.

Fig. 1 show three shocks that Egyptian economy have been faced, first shock followed the financial crisis in Southeast Asia from 1997 to 1999. Second Shock followed the global financial crisis from 2008 to 2009. Third shock followed internal crisis resulting from the social revolution on Jan. 25 from 2011 until now. Also, it shows that during the shock of $1997-1999$ there is a decline in total revenue accompanied with an increase in total spending, which led to a decline in international reserves volume. And during the 
2008-2009 shock it is noted a decrease in total revenue accompanied with a decrease in total spending and a slight rise in the volume of international reserves. While during 2011 shock, it shows a slight decline in total revenue accompanied with an increase in total spending, but also noted a sharp drop in the volume of international reserves.

More deeply studying the total income and the total expenditure components, we found that the main pillars of total income is the value of exports of goods and services and the value of personal remittances of workers' abroad and that the main pillars of total expenditure is the value of imports of goods and services and the value of external debt installment. Fig. 2 shows that during the shock of 1997 1999 there is a decline in the value of exports of goods and services and the value of relative stability in personal remittances accompanied with increase in the value of imports of goods and services and the stability in the value of external debt installment. And during the 2008-2009 shock, it is noted a decline in the value of exports of goods and services and a slight decline in the value of personal remittances accompanied with decline in the value of imports of goods and services and the relative stability in the value of external debt installment. And during 2011 shock, it is noted a sharp decline in the value of exports of goods and services accompanied with a sharp rise in the value of imports of goods and services and the relative stability in the value of external debt installment, while the remarkable mater was the significant increase in the value of personal remittances from workers abroad, which is economically unjustified.

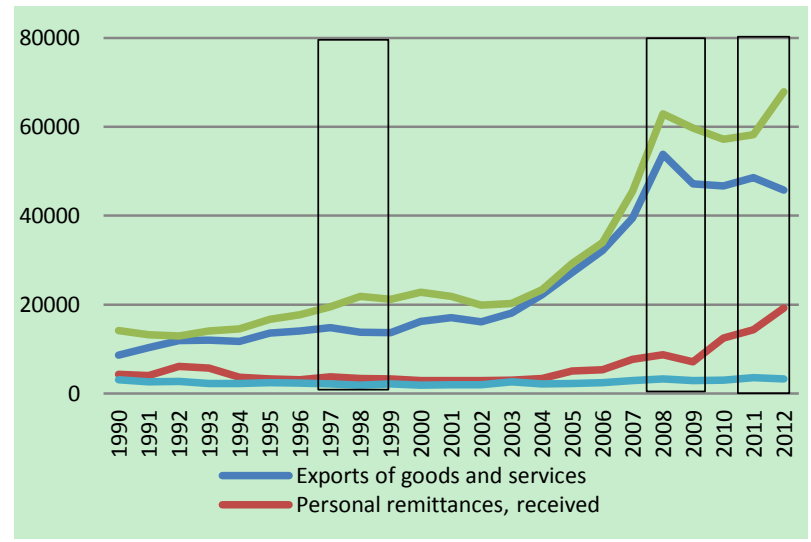

Fig. 2. Egyptian Income and payment resource.

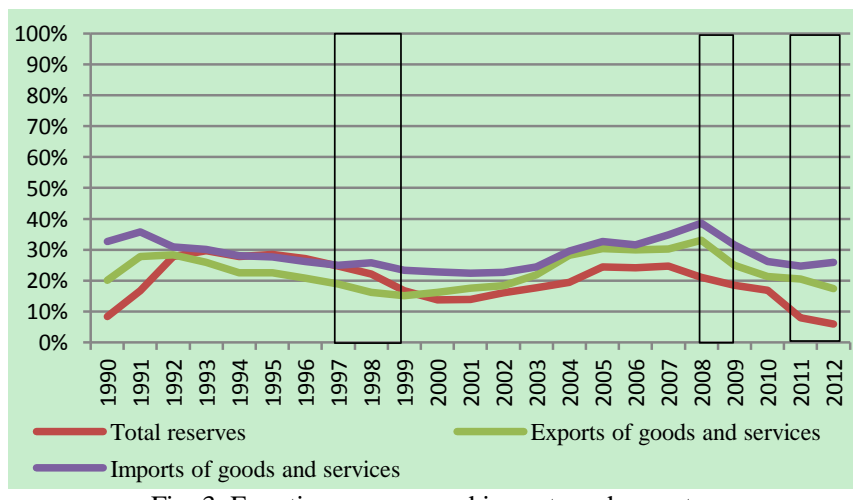

Fig. 3. Egyptian reserves and imports and exports.

As it can be seen in Fig. 3, show exports and imports of goods and services as a percentage of GDP were relatively unstable in the crisis periods. It can be seen in the cries of
1997 and 2008, there has been a decline worldwide trade, which has decline the Egyptian export. In 2011 crisis, it was a Labor protests and social revolution leads to export decline.

Fig. 4 shows that reserves was equal to the imports of goods and services but starting from 1997 -1999 there is a decline in reserves and increasing in imports especially with the beginning of 2011 shock.

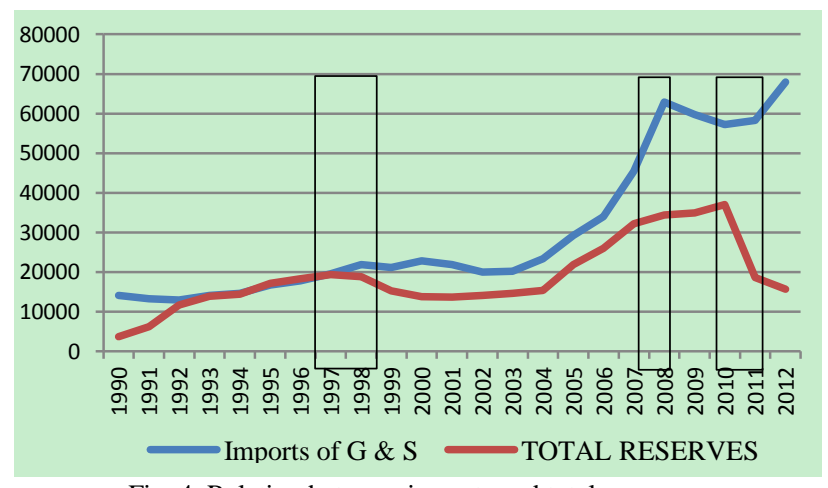

Fig. 4. Relation between imports and total reserves.

In the context of this paper, this implies a risk indicator that is higher than in the past, which could lead to an increase in the need of foreign reserves.

\section{Methodology}

\section{A. The Basic Model}

The most traditional model used to explain the international reserves is the buffer stock model. According to the model the authority demand reserves as a buffer to mitigate fluctuation in external payments imbalances. The lack of sufficient reserves often leads authorities to implement policies to reduce expenditure in order to rebuild reserves which may result in loss of output. This was defined as "the macroeconomic adjustment cost" which implies that the high cost of adjustment leads to increased demand for international reserves.

Our model based on Frenkel and Jovanovic 1981, who assume that changes in reserve holdings can be characterized by the following equation as a weiner process where the incremental change in reserves in a small time interval is distributed normally

$$
d R_{t}=\mu d_{t}+\sigma d W_{t}
$$

where $R_{t}$ is reserves held in time $(t)$ and $W_{t}$ is the standard Wiener process with mean zero and with variance $t$.

At each point of time the distribution of reserve holdings $R_{t}$ is characterized by:

$$
R_{t}=R_{0}-\mu d_{t}+\sigma d W_{t}
$$

and

$$
R_{t} \sim N\left(\mathrm{R}-\mu_{t}, \sigma_{t}^{2}\right)
$$

where R denotes the initial stock of reserves which is assumed to be the optimal level, $\mu$ denotes the deterministic part of the instantaneous change in reserves.

We can define the level of reserves, taking into consideration two types of costs, (i) the cost of adjustment which is incurred once reserves reach an undesirable lower 
bound, (ii) foregone earnings on reserve holdings. The two costs are interrelated, where a higher stockpile of reserves reduces the expected cost of adjustment. On the other side, the high level of security is acquired at the cost of higher forgone earning. The stock of reserves yields the combination of being able to finance a deficit by drowning on reserves and of having to adjust in the face of a deficit by reducing expenditures [5]. Based on the foregoing, the level of reserves $R$ is obtained by minimizing the two types of costs.

In the special case of no reserve drift between stock adjustments (the difference between payments and receipts in international transactions is without a drift) the reserve holdings can be expressed as follows:

$$
\hat{\mathrm{R}}=\sqrt{\left[\frac{C \sigma}{o^{0.5}}\right]}
$$

where $C$ is the fixed cost of adjustment, $\sigma$ is the standard deviation of change in reserves and $O$ is the opportunity cost of holding reserves.

Equation (3) shows that, in the buffer stock model, reserve holdings increase with the volatility of reserves $\sigma$ ). It means that the authority is willing to stockpile a large amount of reserves and tolerate greater opportunity cost in order to incur less adjustment cost. The equation also shows that a higher opportunity cost reduces reserve holdings while a bigger adjustment cost increases them [6]. In The empirical works the estimation equation becomes as follows:

$$
\log _{t}=a_{0}+a_{1} \log \sigma_{t}+a_{2} D \log O_{t}+u_{t}
$$

where $u$ is white noise

We extended the model presented by Frenkel and Jovanovic (1981) to incorporate some additional variables which are important in determining the level of international reserves for Egypt.

The contrast between countries about the amount of what they held from international reserves cannot be compared or traced through time unless they are scaled in some way to reflect differences in size [13]. Many early estimates of reserve holdings included a scale variable such as GDP, imports, GDP per capita, or M2 as separate regressors. The justification of including the scale variable to the buffer stock equation is that reserve holdings should increase with the size of international transaction, so we would expect reserve holdings to be positively correlated with the country's population and standard of living

[3]. In additional to the scale variable, we will also add a variable representing the exchange rate according to its important as a market determined in Egypt at the beginning of the nineties since the authority switching to more flexible exchange rate arrangements. According to the above, our buffer stock equation is written as:

$$
\begin{gathered}
\log _{t}=a_{0}+a_{1} D \log _{t}+a_{2} D \log _{t}+a_{3} D \log \sigma_{t}+ \\
a_{4} D \log O_{t}+e_{t}
\end{gathered}
$$

where $R_{t}$ is reserves held, $S_{t}$ is the scale variable. $r_{t}$ is the exchange rate, $\sigma_{t}$ is the volatility of international transactions, $O_{t}$ is the opportunity cost of holding reserves, $e_{t}$ is the white noise error term.

\section{B. Data Description and Sources}

This study employs four independent variables in order to investigate relationship with reserves. Reserves $(R)$ is the international reserves including gold. The scale variable can be determined in the GDP. Exchange rate $(r)$ is defined as the logarithm of the standard deviation of the quarterly change in the exchange rate with respect to U.S. dollar. The volatility of international transactions $(\sigma)$ will be expressed by volatility of real exports receipts, measured as (std.dev ( $\Delta$ Exports)/ave(GDP)). The opportunity cost of holding reserves $(O)$ plays a central role in all models on demand for foreign exchange (usually approximated by a country's government bond yield). Quarterly data from 1990Q1 to 2012Q4 obtained from International monetary fund, Central bank of Egypt and World Development Indicators web sites.

\section{The Estimations Procedure}

For estimating equation (5) we use the bound test procedure. The autoregressive distributed lag ARDL developed by Pesaran et al. According to Pesaran "the ARDL is being employed for cointegration analysis since it can be applied irrespective of whether the regressors are $\mathrm{I}(0)$, I(1) or mutually cointegrated. Moreover, it is unnecessary that the order of integration of the underlying regressors be ascertained prior to testing the existence of a level relationship between two variables $y_{t}$ and $x_{t}$ " [14].

The procedure for estimating the equation according to the ARDL can be determined in two steps, the first is Wald test (F-statistic version of the bound testing approaches). We test the null hypothesis of non-cointegration relation between the variables $\left(H_{0}: \alpha_{1}=\alpha_{2}=\alpha_{3}=\alpha_{4}=\alpha_{5}=0\right)$ by performing a joint significance test on the lagged level variables. Pesaran et al., (2001) tabulated two sets of critical values, these two sets covering a band between $\mathrm{I}(0)$ and $\mathrm{I}(1)$ which gives three possibilities. First, if the test statistic (Fstatistic) falls below the lower critical bound, the null hypothesis cannot be rejected which means that there is no cointegration between the variables. Second, if the Fstatistic exceeds upper critical bound, the null hypothesis is rejected indicating that there is cointegration relation between the variables. The result will be inconclusive if the F-statistic falls within the band

The second step of ARDL approach is to estimate the coefficients of the long run cointegrating relationship and corresponding ECM.

$$
\begin{aligned}
& D \log R_{t}=b_{0}+\sum_{i=1}^{n} a_{i} D \log R_{t-1}+\sum_{i=1}^{n} b_{1 i} D \log S_{t-1} \\
& +\sum_{i=1}^{n} b_{2 i} D L o g r_{t-1}+\sum_{i=1}^{n} b_{3 i} D \log \sigma_{t-1} \\
& +\sum_{i=1}^{n} b_{4 i} D \log O_{t-1}+\alpha_{1} \log R_{t-1} \\
& +\alpha_{2} \log _{t-1}+\alpha_{3} \log _{t-1} \\
& +\alpha_{4} \log \sigma_{t-1}+\alpha_{5} \log O_{t-1}+u_{t}
\end{aligned}
$$

The lagged error correction term $\left(e_{t-1}\right)$ derived from the ECM model is an important element in the dynamics of cointegrated system as it allows for adjustment back to the long-term equilibrium relationship. Since the observations 
are on quarterly basis, for maximum order of the lags in the ARDL model, we choose lags of 4 . The appropriate lag structure of the ECM is determined by three model selection criteria: Akaike Information Criteria (AIC), Schwarz Bayesian Criteria (SBC), and Adjusted LR Test.

\section{EMPIRICAL RESULTS AND DISCUSSION}

Because of the importance of the lag length in estimating the ARDL regression, the test run over 4 lag length to determine the optimal lag length. However, lag length determine by AIC and SBC produced contradict results. AIC suggests lag length of 4 while SBC and LR test suggests lag length of 1 . Table I, shows that lag length of 1 has been determined.

TABLE I: CHOICE CRITERIA FOR SELECTING THE ORDER OF THE VAR MODEL

\begin{tabular}{|c|c|c|c|}
\hline Order & AIC & SBC & LR \\
\hline 0 & -53.6871 & -61.4143 & 306.5867 \\
\hline 1 & 219.5866 & $140.1410^{*}$ & $160.8828^{*}$ \\
\hline 2 & 204.1664 & 62.8023 & 125.6021 \\
\hline 3 & 227.5140 & 34.3414 & 64.0340 \\
\hline 4 & $260.8278^{*}$ & 14.8268 & - \\
\hline
\end{tabular}

$\mathrm{AIC}=$ Akaike Information Criteria $\mathrm{SBC}=$ Schwarz Bayesian Criteria $\mathrm{LR}=$ Adjusted LR test

In Table II, we find the computed F-statistics for Egypt is 5.0913 (0.001) exceed the upper bound critical value $(2.850$, $4.049)$ at $5 \%$ significant level. So we reject the null hypothesis indicating that there is cointegration relation between the variables. These results reveal a long run relationship between macroeconomic variables and reserve holdings in Egypt.

TABLE II: F-STATISTICS FOR THE EXISTENCE OF LONG RUN RELATIONSHIP

\begin{tabular}{|l|l|}
\hline \multicolumn{2}{|c|}{ RELATIONSHIP } \\
\hline F- statistic & 5.0913 \\
\hline Critical values at 5\% & 2.850 (lower) \\
& 4.049 (upper) \\
\hline
\end{tabular}

The critical values are taken from Pesaran\& Shin (2001), Unrestricted intercept and no trend with four regressors.

From Table III, we can find that error correction term is statistically highly significant and has the negative sign. The long run relationship estimated show that $D \log S$ and $D \log \sigma$, are significant at $5 \%$ level, DLogr and DlogO are insignificant. All the variables have the signs as expected from theoretical propositions.

TABLE III: THE ESTIMATION OF LONG RUN COEFFICIENTS USING THE

\begin{tabular}{|c|c|c|c|}
\hline ARDL \\
\hline Variable & Coefficie & Standard & P-Value \\
\hline$D \log S$ & .20845 & .09063 & $0.031^{*}$ \\
\hline$D \log r$ & -.16356 & .22131 & 0.461 \\
\hline$D \log \sigma$ & .14468 & .05627 & $0.015^{*}$ \\
\hline$D \log O$ & -.0071 & .32213 & 0.073 \\
\hline Inpt & 2.3331 & .55228 & $0.000^{*}$ \\
\hline Ecm(-) & .28713 & 0.08203 & $0.001^{*}$ \\
\hline
\end{tabular}

Note: * denotes significant at $5 \%$ level

Dependent variable DlogR

\section{CONCLUSION}

Use the international reserves as an indicator to measure the national economic efficiency increase the importance of studying the international reserve relationship with other economic variables.

This paper investigates the long run relationship of international reserve holdings with macroeconomic variables over the period from 1990 to 2012 by using Autoregressive Distributed Lag (ARDL) technique. Study results reveal a long run relationship between macroeconomic variables and reserve holdings in Egypt. Also, show that reserve demand is positively related to the scale variable (GDP) and volatility of exports. In spite of the importance of the opportunity cost in determining international reserve holdings, the most empirical studies have not been able to find a significant effect of the opportunity cost.

In this study, the opportunity cost is not significant variable influencing international reserve holdings in Egypt. This may be because that traditional proxy for opportunity cost does not properly capture the true opportunity cost of holding reserves. in the same time, study results indicate that the exchange rate is insignificant variable. This is despite the fact that Egypt applies flexible exchange rate policy since the nineties, however this result suggests two things, first the insignificant of the exchange rate may be due to the monetary authorities in Egypt is intervening directly or indirectly to mitigate fluctuations in the exchange rate in order to maintain export competitiveness. The second is that this variable may not capture the exchange rate flexibility for the Egyptian economy which would require modifications on this variable to measure the exchange rate flexibility accurately.

\section{REFERENCES}

[1] E. Dabla-Norris, J. Kim, and K. Shiron, "Optimal precautionary reserves for low-income countries: A cost-benefit analysis," IMF Working Paper, 11/249, 2011.

[2] A. Frenkel, "Mundell-fleming lecture: Contractionary CURRENCY crashes in developing countries," IMF Staff Paper, vol. 52, no. 2, 2005.

[3] J. Aizenman and N. Marion "The high demand for international reserves in the far east: What's going on?" NBER Working Paper no. 9266, 2002.

[4] R. Heller, "Optimal international reserves," Economic Journal, vol. 76, pp. 296-311, 1966.

[5] A. Frenkel and B. Javanovic, "Optimal international reserves: A stochastic framework," Economic Journal, vol. 91, pp. 507-514, 1981.

[6] R. Flood and N. Marion, "Holding international reserves in an era of high capital mobility," IMF Working Paper 02/62, 2002.

[7] L. Philip and B. Dominic, "The empirics of foreign reserves," Open Economies Review, Springer, vol. 12, no. 4, pp. 423-434, 2001.

[8] M. Dooley, D. Folkerts-Landau, and P. Garber, "The revived bretton woods system: The effects of periphery intervention and reserve management on interest rates and exchange rates in center countries," NBER Working Paper No. 10332, 2004.

[9] J. Aizeneman and J. Lee, "International reserves: Precautionary versus mercantilist views, theory and evidence," IMF Working Paper 05/198, 2005.

[10] M. Dooley, D. Folkerts-Landau, and P. G arber, International Financial Stability: Asia, Interest Rates, and the Dollar, Deutsche Bank Global Research, 2005.

[11] M. Ramachandran, "High capital mobility and precautionary demand for international reserves," Journal of Quantitative Economics, vol. 3, no. 2, pp. 15-29, July 2005.

[12] B. Christopher and R. Javier, "International reserve holdings: Interest rates matter!' Applied Economics Letters, Taylor \& Francis Journals, vol. 16, no. 4, pp. 343-348, 2009. 
[13] R. Demarmels and A. Fischer, "Understanding reserve volatility in emerging markets: A look at the last thirty years," Study Center Gerzensee, working paper 0202, 2002.

[14] P. Shin and R. Smith, "Bound testing approaches to the analysis of level relationship," Journal of Applied Econometrics, vol. 16, pp. 289-326, 2001

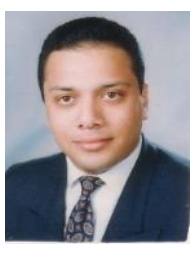

Osama M. Badr was born in Egypt in 1964. He received his B.Sc. degree in economics from Tanta University in 1986 and his M.Sc. degree in applied economy from Tanta University in 1998. He earned his $\mathrm{Ph} . \mathrm{D}$. in economics from the same university in 2007. He received his diploma of financial analyst for Stocks, bonds and other investments from Concordia University, Canada, 1997.

$\mathrm{He}$ is now serving as an assistant professor of economics in College of Management at Umm Al-Qura University, KSA where he joined in 2011. $\mathrm{He}$ works as an economics lecturer in Tanta University since 2006, He worked as an economics assistant lecturer from 1999 till 2006, financial analyst 1993 to 1997, a credit supervisor in Bank of Credit and Commerce from 1987 to 1993. He teaches principles of economics, macroeconomics, public finance, fiscal policy, money and banking, international economy and foreign trade and modern economic problems by relating theories to his six-year experience in banking industry and ten years in financial analyses. His research interest focuses on economic policies and economic growth of developing economies. He has published one English book on fiscal policy and five Arabic books on public finance, fiscal policy, money and banking, foreign trade and modern economic problems.

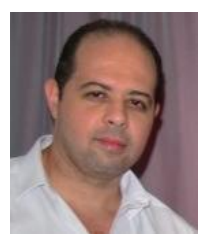

Ahmed F. El-khadrawi was born in Egypt in 1975. He received his B.Sc. degree in economics from Tanta University in 1997 and his M.Sc. degree in applied economy from Tanta University in 2006. He earned his $\mathrm{Ph} . \mathrm{D}$. degree in economics from the same university in 2011.

$\mathrm{He}$ is now serving as an assistant professor of economics in College of Economics at Umm Al-Qura University, KSA where he joined in 2012. He worked as an assistant economics researcher in Tanta University from 1997 to 2006. He worked as an economics assistant lecturer in Damietta University from 2006 till 2011. He teaches principles of economics, macroeconomics, money and banking, international economy and modern economic problems. His research interest focuses on international macroeconomic and trade. He has published five Arabic economics books. 